\title{
Impact of Industrial Revolutions on Food Machinery - An Overview
}

\author{
Afam I. O. Jideani ${ }^{1}$, Awelani P. Mutshinyani ${ }^{1,2}$, Ntsako P. Maluleke ${ }^{1}$, Zwivhuya P. Mafukata ${ }^{1}$, Mkateko V. $^{2}$ \\ Sithole $^{1,3}$, Mashudu U. Lidovho, ${ }^{1,4}$, Edwin K. Ramatsetse ${ }^{1} \&$ Monica M. Matshisevhe ${ }^{1}$ \\ ${ }^{1}$ Department of Food Science and Technology, School of Agriculture, University of Venda, Thohoyandou, 0950 \\ South Africa \\ ${ }^{2}$ Hardyware Food Technologies (Pty) Ltd, Unit 38, 56 Sunbeam Street, Icon Industrial park, Centurion, 0157, \\ South Africa \\ ${ }^{3}$ Ekuzeni Supplies (Pty), Plot 22 Lazaar Ave, Wheatlands, Randfontein 1759, South Africa \\ ${ }^{4}$ Meat Science Department, Agricultural Research Council, Irene Campus, Old Olifantsfontein Road, Private \\ Bag X2, Irene, 0062, South Africa \\ Correspondence: Afam I. O. Jideani, Department of Food Science and Technology, School of Agriculture, \\ University of Venda, Thohoyandou, 0950 South Africa. E-mail: Afam.Jideani@ univen.ac.za \\ https://orcid.org/0000-0002-9122-8697
}

Received: June 10, 2020

doi:10.5539/jfr.v9n5p42
Accepted: July 11, $2020 \quad$ Online Published: July 29, 2020

URL: https://doi.org/10.5539/jfr.v9n5p42

\begin{abstract}
The industrial revolutions occurring at specific periods impacted differently on food industry machinery, including analytical and innovative scientific equipment, and had significant effects on food manufacturing. The fourth industrial revolution (4IR) unlike the other industrial revolutions (1IR, 2IR, and 3IR) has a faster significant impact and niches on artificial intelligence (AI), machine learning (ML), blockchain, robotics, the internet of things (IoT), digitalization, big data, autonomous vehicles, additive manufacturing, nanotechnology, biotechnology, and 3D food printing technologies. Going forward would require more mechatronic engineers as process technicians, particularly in paperless processes and automation of the digital rich future.
\end{abstract}

Keywords: industrial revolution, machines, food, industry, 4IR, digitalization, artificial intelligence, machine learning, robotics, blockchain

\section{Introduction}

Different forms of technologies have been enablers over the centuries in the food industry. Each emerging technology is characterized by the introduction of transformational new technologies into manufacturing. The four industrial revolutions (IR) occurring at a specific period in history impacted differently on food industry machinery, including analytical and scientific equipment, and had significant effects on food processing and products. Technology has been an enabler in the food industry. The industrial revolution began around 1780 with the introduction of mechanical production plants powered by liquid water or steam. The second industrial revolution (2IR) came after about 30 years when the first mechanical assembly line powered by electricity was constructed. Around the 1960s, the third industrial revolution (3IR) with new technologies, internet, and the renewable energies changed history (Strozzi et al., 2017). The fourth industrial revolution (4IR), coined as late as 2016 by Schwab during the World Economic Forum in Dovos, makes use of automation, deep mechanism, and digitalization (Prisecaru, 2016) niching on artificial intelligence (AI), machine learning (ML) and robotics. The use of novel techniques in the food industry over the centuries has seen increasing high-pressure processing usage around the globe, including the development of powered machines such as automated extrusion. North America and Mexico (54\%) are ahead in high pressure (HP) usage for high-value products compared to Europe $(25 \%)$, Asia (12\%), and Africa (1\%). It is possible that industrial revolution periods slightly overlap (Tables 1) and not strictly distinct for start and end dates. Hence, merging of technologies over the centuries evolved into the new technology of the period under consideration. Such merging will enable having an insight into 5IR in every process, including innovative printed reactors. The fourth industrial revolution (4IR) unlike the other industrial revolutions (1IR, 2IR, and 3IR) has a faster significant impact and niches on artificial intelligence (AI), machine learning (ML), blockchain, robotics, the internet of things (IoT), digitalization, big data, autonomous vehicles, additive manufacturing, nanotechnology, biotechnology, and 3D food printing technologies. 


\section{The First Industrial Revolution and the Impact on Food Machinery}

The first industrial revolution (1IR) was the transition to new manufacturing processes in the period from about 1760 to sometime between 1820 and 1900 (Strozzi et al., 2017). This transition included going from hand production methods to machines for processing with mechanical production equipment driven by water and steam power (Crafts, 2006) but without digitalization(Tables 1). Important technological developments involved mechanized cotton spinning powered by steam or water (Prisecaru, 2016). A mechanization machine replaces animal and manual labor from the late 18th to early 19th century. The adaption of stationary steam engines to rotary motion in food processing machines made them suitable for in food industries. Traditionally, drying was applied to both animal and vegetable products and relied primarily on the action of the sun and wind (Klein, 2008; Anderson, 2015).

Table 1. Main characteristics of industrial revolutions (adapted from Prisecaru, 2016)

\begin{tabular}{|c|c|c|c|c|c|}
\hline $\begin{array}{l}\text { Industrial } \\
\text { revolution } \\
\text { (IR) }\end{array}$ & $\begin{array}{l}\text { Transition } \\
\text { period }\end{array}$ & $\begin{array}{l}\text { Energy } \\
\text { resource }\end{array}$ & Main technology & Food machines & Illustration \\
\hline $1^{\text {st }}$ IR & $1780-1900$ & Coal & Steam engine & Textile, steel & \\
\hline $2^{\text {nd }} \mathrm{IR}$ & 1940-1960 & $\begin{array}{l}\text { Oil } \\
\text { electricity }\end{array}$ & $\begin{array}{l}\text { Internal } \\
\text { combustion } \\
\text { engine }\end{array}$ & $\begin{array}{l}\text { Extrusion line for } \\
\text { pasta production }\end{array}$ & \\
\hline $3^{\text {rd }}$ IR & $1960-2000$ & $\begin{array}{l}\text { Nuclear } \\
\text { energy }\end{array}$ & $\begin{array}{l}\text { Computers, } \\
\text { Robots }\end{array}$ & $\begin{array}{l}\text { Automated cooking } \\
\text { extruders, }\end{array}$ & \\
\hline $4^{\text {th }}$ IR & Continuing & $\begin{array}{l}\text { Green } \\
\text { energies }\end{array}$ & $\begin{array}{l}\text { Internet, } \quad 3 \mathrm{D} \\
\text { printer, genetic } \\
\text { engineering }\end{array}$ & $\begin{array}{l}\text { Vacuum processing } \\
\text { machine, Electronic } \\
\text { tracing technology }\end{array}$ & \\
\hline
\end{tabular}




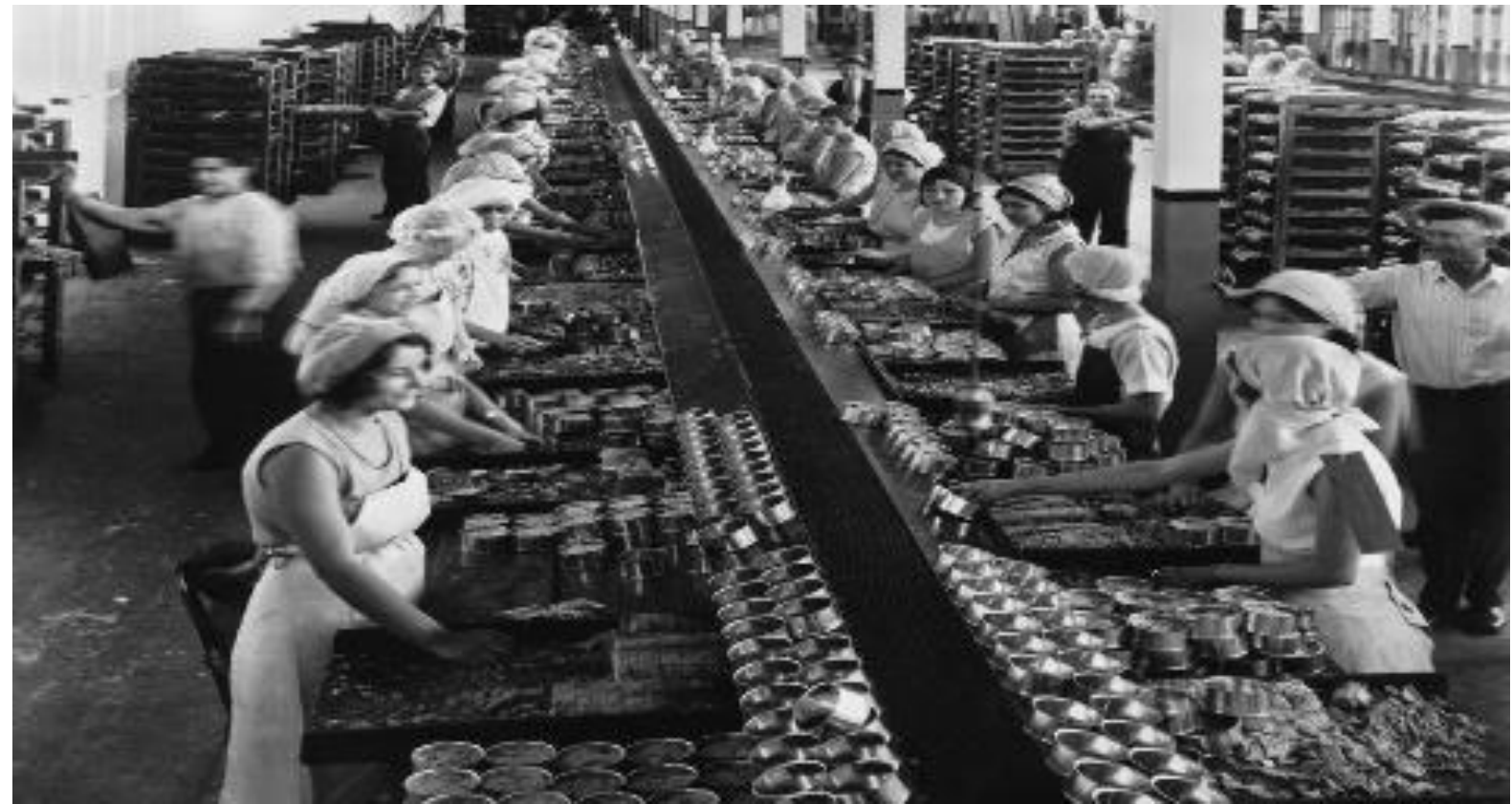

Figure 1 . Workers in canning company during the $1^{\text {st }}$ industrial revolution

https.//teara.govt.nz/files/p-23079-enz.jpg

In 1771 marked the first fully automated spinning mill driven by water power. Hermetic bottling techniques were invented in 1809 by a French chef, confectioner, and distiller using corked-glass containers reinforced with wire and sealing wax. The canning method used to preserve food was invented during the 1IR. A famous French investor developed a special autoclave for food canning in 1823 (Barbier, 1994). Steam sterilizing machine, metal detector, continuous freeze dryer, microwave vacuum dryers, twin-screw cooker/extruder, mixer with the electric motor, and microprocessor-controlled packaging machinery marked this period. Most food industries during 1IR developed packaging methods for food such as canning as shown in Figure 1.

The 1IR impacted food machinery by i) machines invention that replaced human labor: involving the transition from hand production methods to machines in food industries, increasing use of steam power replacing water wheels, development of machine tools, and the rise of the mechanized factory system. These machines increased mass production, the number of goods and diversity of goods produced (Malek, 2005); and ii) new energy sources to power machinery in food industries. Steam engines (Figure 2) replaced water wheels to power machines used in food factories (Malek, 2005). A good example was the Albion flour milling machine, Southwark, Surrey UK, (Salmon, 1843) powered by steam engines which replaced a water-powered grist mill.
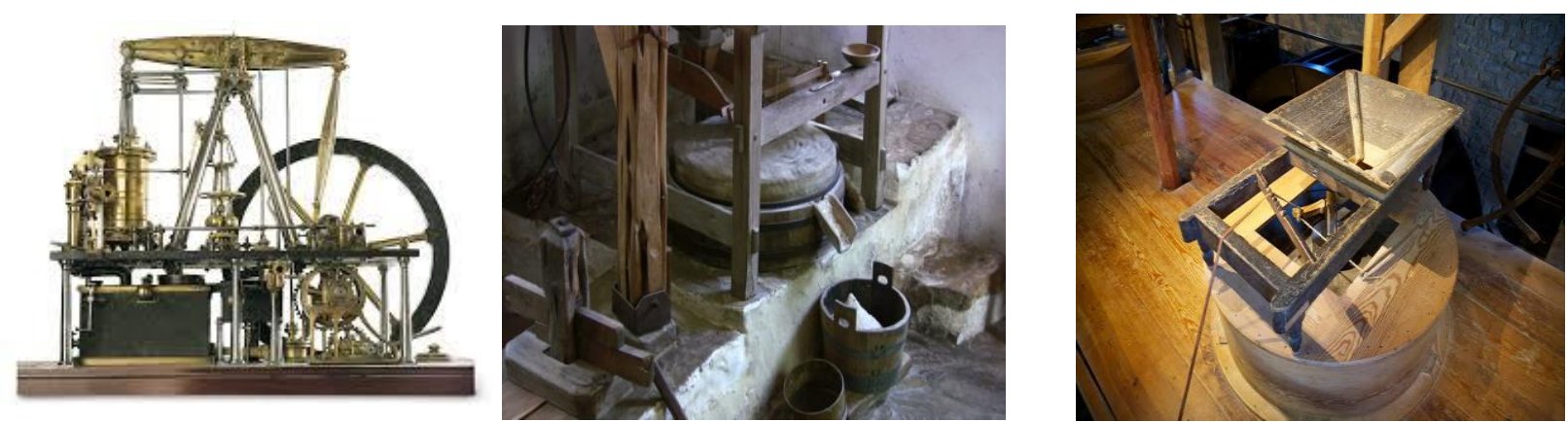

Figure 2. Steam-powered Albion mill (1786), Water powered Grist mill (1787), and Watt steam engine (1776), respectively, Patrick and Clay (2012), Salmon (1843), Vernon (2019) 


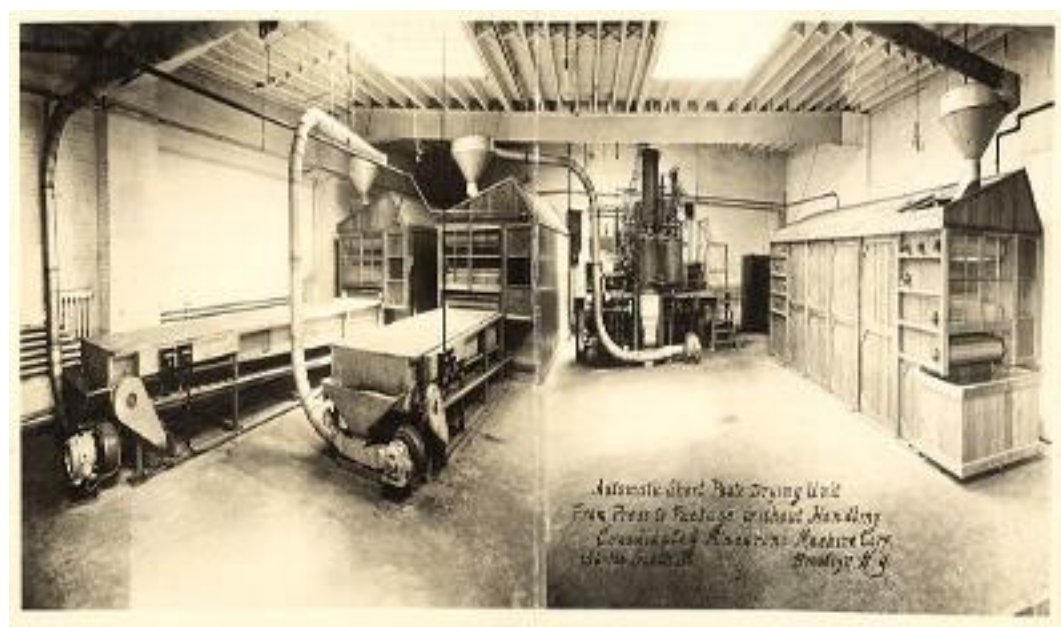

Figure 3. Dry pasta manufacturing line from the 1930s

https://en.m.wikipedia.org//wiki/food_extrusion

\section{The Second Industrial Revolution and the Impact on Food Machinery}

The second industrial revolution (2IR) was based on mass production achieved by division of labour concept and the use of electrical energy (Table 2), machines, and processes from the late 19th to late 20th century (Crafts, 2004). Instead of using water and steam power, most food industries used electricity-powered machines that reduce production time in bakeries, dairy industry, larger agricultural estates, and other food processing centers (Fremdling 2008). Steam engines were replaced by electricity as a primary power source to power food industries and machines (Muntone, 2013). The Bessemer process (Sheffield, England) used to make strong steel was introduced enabling better and stronger machines used in food industries to replace weak iron (Muntone, 2013). The 2IR was noticeable by the chemical industry, mechanical engineering, and the food industry (Adnan et al, 2017). The sources of energy were oil and electricity (Adnan et al., 2017). Mass production played a lead role in the revolution. The introduction of assembly lines increased automation as machines were combined and reduced the production time (Muntone, 2013). Common examples of food machinery were: i) first semi-automated extruder that uses electricity designed to manufacture packaged dry pasta and breakfast cereals around the 1930s (Figure 3), ii) refrigerators (Figure 4a) used to store and cool foods were improved and fans to cool machines during production, and iii) the oven used in oven drying (Figure 4b).

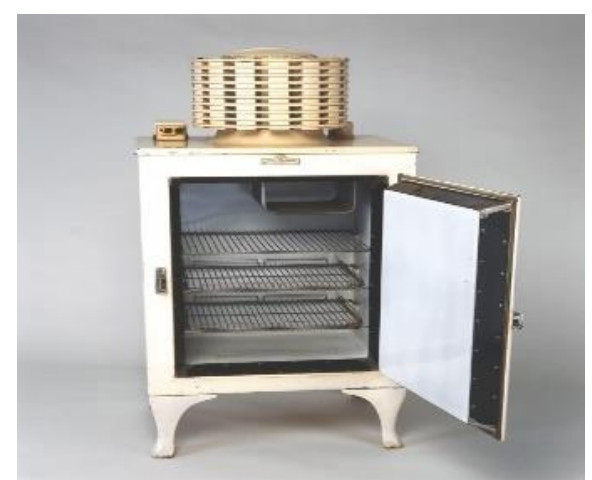

Figure 4a. Improved electric refrigerator

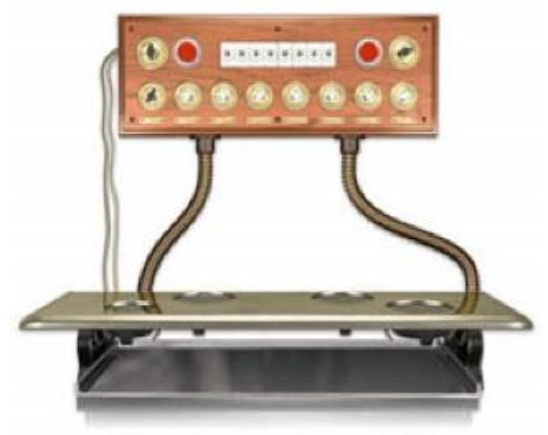

b. The first electric oven of 1892 (Muntone, 2013) 
Table 2. Industrial revolutions and major impact on the development of food machinery

\begin{tabular}{llll}
\hline $\begin{array}{l}\text { Facts on } \\
\text { revolutions (IR) }\end{array}$ & industrial & Food processing machines/machinery & $\begin{array}{l}\text { Impacts (Advantages \& } \\
\text { Implications) }\end{array}$ \\
\hline
\end{tabular}

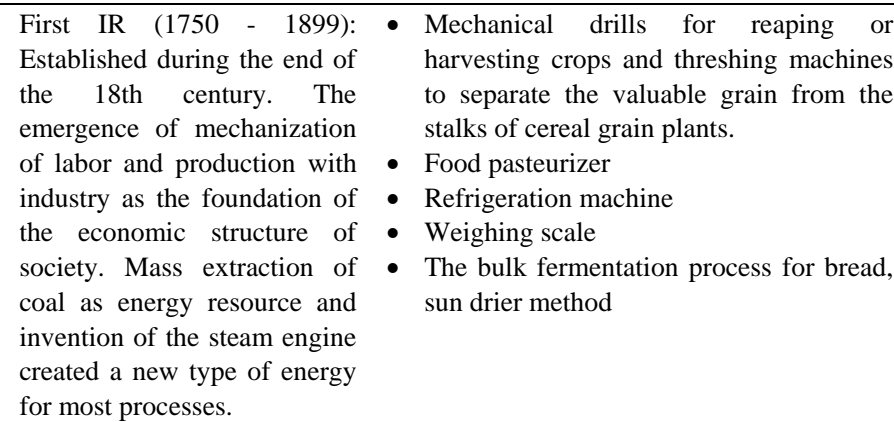
for most processes.

Second IR (1900 - 1960): Started in the second half of the 19th century. The era of rapid industrialization using oil and electricity as an energy resource to power production. New technological advancement initiated the emergence of electricity, gas, and oil. Chemical synthesis also developed to bring synthetic fabric, dyes, and fertilizers. Methods of communication were enhanced with the invention of telephones and so was transportation.

Third IR (1961 - 2000): Computer or the digital revolution. Established during the first half of the 20th century. Advanced technology in the food industry with the emergence of nuclear energy resource whose potential surpassed its predecessors. Witnessed the rise of electronics, with the transistor and microprocessor, telecommunications, and computers. Led to the production of miniaturized material which opened doors, most notably, to space research and biotechnology.

Fourth IR (2000 - present): Typified by green energy resource. Blurring of boundaries between the physical, digital, and biological worlds. Internet of things (IoT) commonly known as industry 4.0 or 4IR.
- Drum, spray, rapid freeze driers, brine injector technology, juice extractors, milk pasteurizer, tubular blanchers.

- Improvement in agro-processing equipment like wheat harvesting tractors and separation machines.

- Food canning, sterilizing/pasteurization, flash freezing machines, electric standing mixer (1908) by Herbert Johnson. Cherry Burrell corps - developed continuous pasteurization system Automated check pouch packaging machine (1967).

- Magnetrons microwave ovens (invented by Albert W. Hull), a device to generates microwaves using electricity. One of the first electric food processes was the Star mix MX3 food processer by German company electro star in 1946. First artificial food refrigeration machine (1955) by Willem Colleen.

- High-temperature short-time automatic pasteurizer, Chorleywood bread process, electrical stimulators

- The Twin-rotor system combines machine to cut and separate crops or fresh produce.

- Mobile software development to help farmers exchange ploughing, harvesting, and food preparation information

- Use of genetic modification technology and equipment to improve crop performance and increase yields.

- The invention of vacuum pouch the packaging machine (1967); high-pressure short time cooker/extruder (1964), first can-opener (1970), vacuum pressure system (1972), cook quench the chill machine (1997) and Sous vide equipment (1986).

- Novel vacuum processing machine, high-pressure processing technology, thermal and non-thermal retorting systems, electronic tracing technology, intelligence labelling, and computerised colour reflex, automatic fruit juice pasteurizer using microwaves/ultrasonic waves, hot air tray drier incorporated with computer vision; weighing machine (1947) and vacuum
- Mechanical harvesting and Chaloner, 1957; threshing of grains.

- Preservation of food using high-temperature steam and water to kill microorganisms.

- Preservation of food by cooling and freezing.

- Weighing scale for use in scaling of raw ingredients during processing and sale.

- Production of equipment used in the processing of food

- Environmental pollution of air high due to heat energy requirement of machines with the release of smoke

- Rapid industrialization using oil and electricity to power mass production.

- Horsepower replaced by an internal combustion engine.

- Increase in food supply due to increased crop production and improved separation processes.

- Increased food preservation, sterilization by canning, and food safety.

- Enhanced food production due to electricity and reduced food industry working time.

- The use of equipment operated with oils or gas harmed processed food, especially with changes in color and aroma.

- Electronic and IT assisted in the automation of the production/manufacturing industry, increasing food production by more than $1000 \%$ in some cases.

- Computerized food processing equipment for pasteurization, sterilization, dehydration (freeze-drying), and automatic beer filtration systems.

- Analytical food laboratory using computers and highly advanced machines/ equipment.

- High energy consumption of machines.

- Ultra-centrifugal milling with extreme milling rate and competency.

- Time-saving, improve productivity and reliability.

- Digitalization of machine operation able to analyze different parameters in a short period,
Mingay, 1966;

Marwala \&

Hurtiz, 2017;

Rhoades, 2017;

Min, et al 2018;

Sentryo, 2018;

Prisecaru, 2019

Chambers \& Mingay, 1966; Rifkin, 2013; Marwala \& Hurtiz, 2017; Min, et al 2018; Salesforce, 2019; Prisecaru, 2019. Rifkin, 2011; Jee, 2017; Min, et al 2018; Sentryo, 2018; Prisecaru, 2019

Atzori, et al, 2010; Anderson, 2012;

Al-Rodhan, 2015; Agrifood, 2017; Colombo, et al 2017; Jee, 2017; Marwala
Chambers \&

Chaloner, 1957 ; Höller, 2014; 


\begin{tabular}{|c|c|c|c|}
\hline $\begin{array}{l}\text { A fusion of advances in } \\
\text { artificial intelligence (AI), } \\
\text { robotics, 3D printing, genetic } \\
\text { engineering, quantum } \\
\text { computing, blockchain, } \\
\text { intelligent labelling, and other } \\
\text { technologies. The collective } \\
\text { force behind many products } \\
\text { and services that are fast } \\
\text { becoming indispensable to } \\
\text { modern life. Very scalable } \\
\text { industry. }\end{array}$ & $\begin{array}{l}\text { Hybrid convective-infrared-rotary drum } \\
\text { dryer. } \\
\text { - } \text { Automated ultra-centrifugal milling } \\
\text { - } \text { Texture analyzing and sensory evaluation } \\
\text { machines } \\
\text { - Automation and digitalization of } \\
\text { processes; tracking of materials and } \\
\text { packaging through the utilisation of radio } \\
\text { frequency identification (RFID) tags and } \\
\text { ERP systems. } \\
\text { - Development of jet cook stem infusion } \\
\text { system (2006). Food processing robots and } \\
\text { robotic machines performing different } \\
\text { functions for food manufacturers. } \\
\text { - Improvement of food analysis machines. } \\
\text { Green extraction technologies, Pulsed } \\
\text { electric field technology }\end{array}$ & $\begin{array}{l}\text { reduction of workload, and time to } \\
\text { complete tasks. } \\
\text { - Predictability of outcome of a } \\
\text { process } \\
\text { - Replacement of manual labour by } \\
\text { robots and machines. A new skill } \\
\text { set will be needed to operate the } \\
\text { robots. }\end{array}$ & $\begin{array}{l}\text { \& Hurtiz, 2017; } \\
\text { Min, et al 2018; } \\
\text { Godoi et al } \\
\text { 2018; } \\
\text { Salesforce, } \\
\text { 2019; Prisecaru, } \\
2019\end{array}$ \\
\hline
\end{tabular}

The 2IR led to significant technological advancement in mobility and production. Henry Ford and others have written about the influence of the slaughterhouse practice whereby in the same factory line, one person would do a specific task, while others did a different one, resulting in meat processed easily and fast (Earle, 2010). Also, the analytical scientific equipment was not left out in these advances. A wide range of commercial driers suitable for both solid and liquid foods was developed, an example was the drum roller drying of milk, and freeze-drying involves freezing followed by sublimation of the ice under reduced pressure (Earle, 2010; Anderson, 2015).

\section{The Third Industrial Revolution and the Impact on Food Machinery}

New technologies, the internet, and renewable energies (Table 2) began to change history (Adnan et al., 2017) of food manufacturing during the third industrial revolution (3IR). Many modern manufacturing facilities with advanced food processing and packaging technologies came into existence. Food products were produced in a new way, using computers and new machines (Maralwa, 2019) leading to the construction of the first automated extrusion machines capable of operating all the steps from raw materials to the final product (Figure 5).

The 3IR was characterized by the implementation of electronics and information technology (IT) to automate production (Maury, 2008). It was based on the use of electronics and IT to further automate production (Fremdling, 2008) but not with much digital "disruption" as in 4IR. Examples include the adoption of i) the Chorleywood bread process, ii) vacuum packaging, as a method of food preservation, and iii) the application of digital printing on food packages (Maralwa, 2019). These developments were pointers to the innovative food packaging that now exists in the $21^{\text {st }}$-century food industry.

Automation and digitalization made possible the introduction of process lines with programmable and automated machines in food industries replacing human labor (Maury 2008). An example is an automated and programmed bakery process line (Figure 6). The technological developments that made these changes possible included innovations in farming machinery, improvements in refrigeration, the mechanization of food processing, and the invention of new packaging materials and promotional techniques (Hawken et al., 2013). The structure of the food system during 3IR raised fresh foods in large quantities far from consumers and made them available for longer periods during the year (Inikori, 2006). 


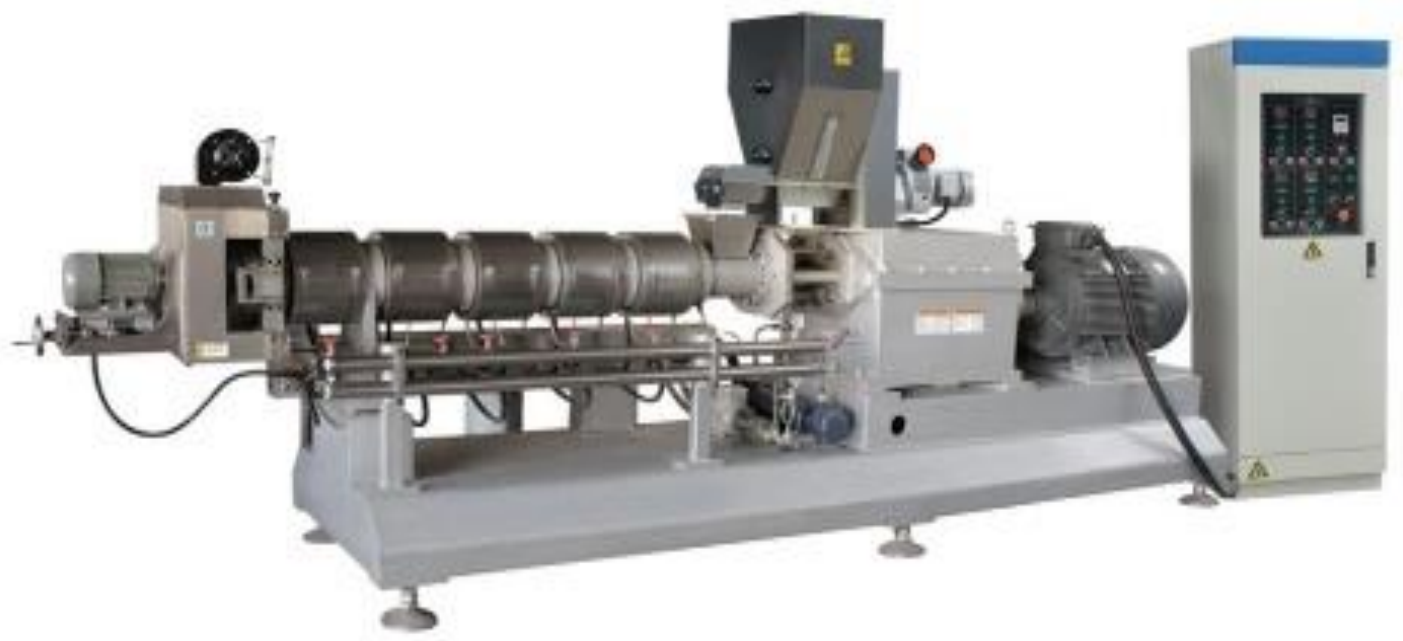

Figure 5. Automated cooking extrusion machine

Source: https://en.m.wikipedia.org//wiki/food_extrusion

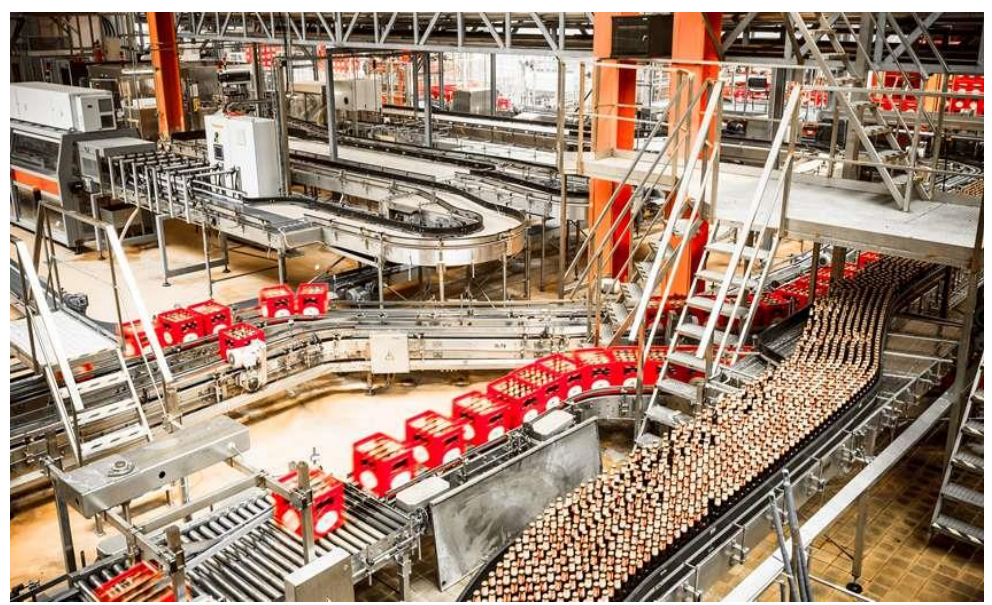

Figure 6. Automated and programmable bakery process line

\section{Fourth Industrial Revolution (From 2000) and Impact on Food Machinery}

The fourth industrial revolution (4IR) is based on the use of cyber-physical systems, automation, analytics, and the internet of things (IoT) from the early 21 st century (Allen, 2009) in the food and agro-processing industries. This evolving food industry trend encompasses advanced technologies of digitalization as outlined in Table 2. It is characterized by making systems as well as machines intelligent and connected (Marwala, 2019). The underlying advances in technologies of the 4IR include artificial intelligence (AI), digitalization, robotics, 3D model as well as blockchain (Pirsecaru, 2019). An application of AI is machine learning (ML) which provides systems the ability to automatically learn and improve from experience without being explicitly programmed. AI enables machines to learn, adapt, evolve, and optimize; and has had a profound impact in diverse fields such as food science and technology, engineering, medical sciences, and social sciences. AI in the food industries is used to create machines that can learn, and it is also used in food sensing technologies for food safety, quality, and traceability (Maury 2008). The digitalization of manufacturing is transforming the way goods are made (Adnan et al., 2017) and AI is already responding to our needs.

The integration of robots in food machinery is now common. Robots can dispense servings of frozen yogurt, ice cream, gelato, and sorbet finished with a selection of six delicious toppings in less than 60 seconds. Robots have been invented that almost completely replace human labour (Maury, 2008, Schwab, 2015). Examples of robots in food industries are i) delta robots (Figure 7) which are used to move, pick, and place products around a production line, and ii) the dispensing robot. Such robots are faster than a human being, with the advantage of 
short production time due to increased speed and accuracy. A low-level palletizer was replaced with a robotic palletizer for loading glass jars onto the sauce line which results in significant line uptime and reduced labour costs (Hawken et al., 2013). There is fear that a robotic takeover of manufacturing jobs will keep humans out of work (Adnan et al., 2017). One common example of industry 4.0 food machines is the vacuum processing machines (Figure 8) to produce food products. The vacuum processing system combines homogenizing technology, the highest reproducibility, short batch times, and high cost-effectiveness with ease to use. Automatic belt vacuum packaging machines and intelligence labelling, that are digitally operated are now in operation in food industries for packaging as well as a preservation method for various foods such as meat products and cheese (Anderson, 2015). The high-pressure processing (HPP) being a non-thermal preservation technology, innovative fluidized freezing technologies, continuous freezer control system, novel heat exchanger (IFMT 2020), and ultrasound-assisted extraction technology are all with great benefits.

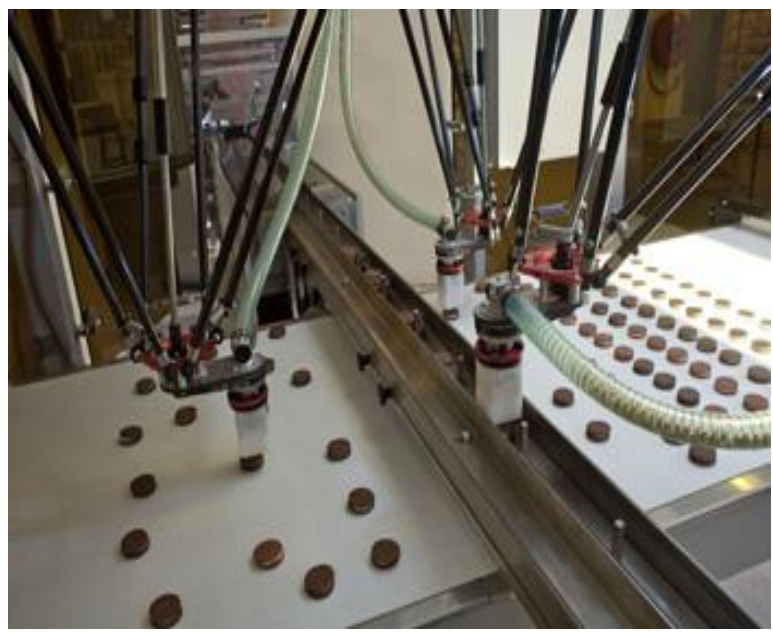

Figure 7a. Delta robot (In Cookie Factory)

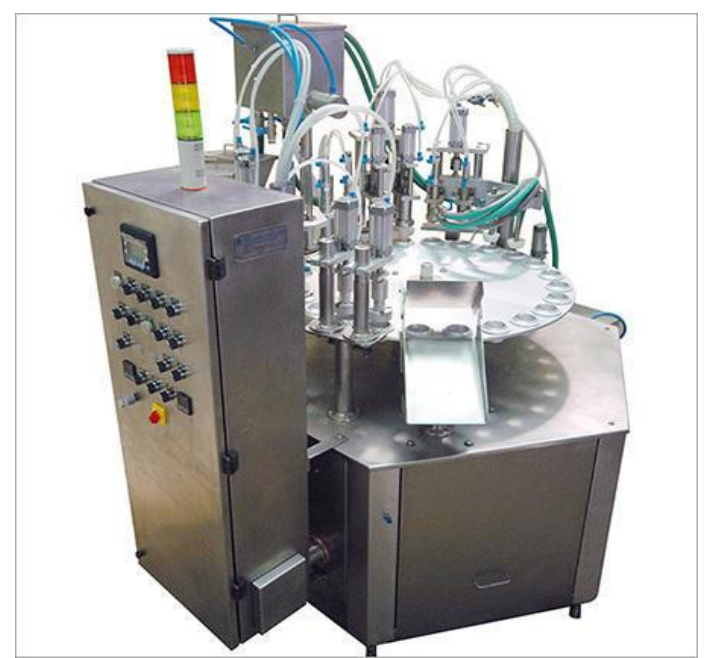

b. Automatic ice cream packaging machine

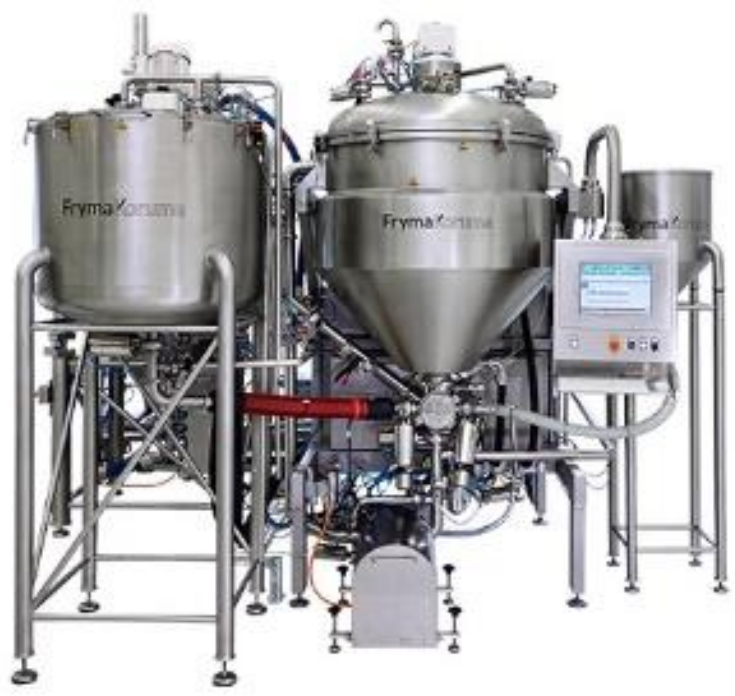

Figure 8. Maxx vacuum processing machine

Source: https://pfrymakoruma.com/ww-en/machinedetails/maxxd/?gclid=EAlalqobChM19r2wrLA4wlVibT tCh3ggwi4EASAYASAAEglsr_d_Bw

The 4IR now involves computer-generated product design and three-dimensional (3D) printing. It is a very scalable industry as technology is said to be a game-changer for scale (Noonan, 2019). Existing advances in this technology include designs, edible ink material, extrusion, and laser-based technologies used during the construction of computer-aided shapes (Godoi et al., 2018). The trio of robotics, 3D model, and blockchain when applied to food machinery has great potential considering that the latter is one example of using data and coupled with AI could solve the nutritional need in specific diets. This is the expectation going forward and beyond 
blockchain in food industry machinery especially with rapidly evolving areas such as IIoT, operational technology cybersecurity, predictive analytics, and edge computing systems. The future holds how a combination of digitalization, robotics, AI, ML, blockchain, quantum computing can help in product development. Blockchain-enabled traceability in the food industry improved value-chain efficiency driven by improved collaboration and data visibility (Nayyar et al., 2018). Also, the advances exist in analytical scientific machines, like x-ray computed tomography, CT scanners that come in different flavors.

\section{Going Forward}

The different industrial revolutions, directly or indirectly, contributed and accelerated improvement and advances in processing equipment from manual operation to more advanced automation, data collection, and analysis. Technologies and processes are evolving at an exponential pace and are increasingly becoming inter-related (Marwala 2020). Although it has created jobs, it also transformed the workforce. From the present trend, and as the digital economies become knowledge-intensive, the demand for higher-order scientific and mathematical skills in food machinery is evident in the technological advancements of industry 4.0. Such skills provide a unique position to strongly contribute to a digital future and expert competence development. The future of food machinery looks exciting with the possible contributions of AI, ML, robotics, and blockchain to industry 5.0. Optimization and prediction with AI by applying ML algorithm to control the food process line, like in the air-conditioning system, is now a possibility using the modular design of the AL/ML engine for adaptive process control. These advanced techniques can help in the collection and processing of data, especially in digital format, and using this digital information to automate operations. Humans are still indispensable, hence modernization and redesign of the global education system with technology-focused subjects such as functional genomics, coding, and data analytics are necessary to prepare learners for the future food industry manufacturing operations. The tweaking of the system is much needed in the global south, which was recently highlighted in a paper in "Nature Sustainability" as an important priority for the research community (Nagendra et al., 2018). Going forward will reveal these emerging technologies in food machinery; including the prospects of food printing at home for domestic application and printing materials such as edible ink types to an innovative and economical printed reactor. Certainly, food industries will increasingly need food engineers, particularly mechatronic engineers and technicians for a good understanding of technologies in food machines of industry 4.0, those of the approaching future industrial revolutions and beyond blockchain. From 3D printing which creates an object that makes food appealing to the digital rich-future $4 \mathrm{D}$ printing such that a processed food requires only the addition of water to create food with desired structural and textural properties. However, 5IR in food machinery may shift attention to humans and not robots for smart science and food chain intelligence.

\section{Conflict of Interests}

The authors declare no conflict of interest.

\section{References}

Allen, R. C. (2009). Economic Structure and Agricultural Productivity in Europe. European Review of Economic History, 3, 1-25.

Anderson, C. (2012). Makers: The New Industrial Revolution. New York: Crown Publishing Group.

Atzori, L., Lera, A., \& Morabito, G. (2010). The internet of things: a survey. Computer Networks, 54(15), 2787-2805. https://doi.org/10.1016/j.comnet.2010.05.010

Anderson, K. (2015). Other preservation methods. In D. Arthey \& C. Dennis (Eds.), Vegetable Processing (pp. 154-85). London: Blackie.

Adnan, N., Nordin, S. M., Rahman, I., \& Noor, A. (2018). The effects of knowledge transfer on farmer's decision making toward sustainable agriculture practices: In view of green fertilizer technology. Journal of Sustainable Technology, 15, 98-115. https://doi.org/10.1108/WJSTSD-11-2016-0062

Al-Rodhan, N. (2015). The Moral Code: How to Teach Robots Right and Wrong. Retrieved from https://www.foreignaffairs.com/articles

Barbier, J. P. (1994). Nicolas Appert Investor and manufacture. CCB Royer Saga Sciences: Paris, France. pp. 208.

Crafts, N. F. R. (2004). Steam as a General Purpose Technology: A Growth Accounting Perspective. Economic Journal, 114(495), 338-351. https://doi.org/10.1111/j.1468-0297.2003.00200.x

Crafts, N. F. R., \& Harley, C. K. (2006). Simulating the Two Views of the Industrial Revolution. Journal of Economic History, 60, 819-841. https://doi.org/10.1017/S0022050700025778 
Chaloner, W. G. (1957). The Agricultural Activities of John Wilkinson, Ironmaster, Agricultural History Review. In J. D. Chambers (Ed.), Enclosure and the Small Landowner. Economic History Review.

Colombo, A. W., Karnouskos, S., Kaynak, O., Shi, Y., \& Yin, S. (2017). Industrial Cyber-physical Systems: A Backbone of the Fourth Industrial Revolution. IEEE Industrial Electronics Magazine, 11, 6-16. https://doi.org/10.1109/MIE.2017.2648857

Dai, L. (2006). From conventional technology to carbon nanotechnology: The fourth industrial revolution and the discoveries of C60, carbon nanotube and Nanodiamond. In L. Dai (Ed.), Carbon Nanotechnology (pp. 3-11). Philadelphia: Elsevier. https://doi.org/10.1016/B978-044451855-2/50004-8

Earle, M. D. (2010). Innovation in the food industry. Trends in Food Science \& Technology, 8, 166-175. https://doi.org/10.1016/S0924-2244(97)01026-1

Fremdling, R. (2004). Continental Responses to British Innovations in the Iron Industry during the Eighteenth and Early Nineteenth Centuries. In L. P. de la Escosura, (Ed.), Exceptionalism and Industrialisation: Britain and Its European Rivals (pp. 145-69). Cambridge, Cambridge University Press. https://doi.org/10.1017/CBO9780511523830.008

Godoi, F. C., Bhandari, B. R., Prakash, S., \& Zhang, M. (Eds.). (2018). Fundamentals of 3D food printing and applications. Academic press. pp. 392.

Höller, J., Tsiatsis, V., Mulligan, C., Karnouskos, S., Avesand, S., \& Boyle, D. (2014). From Machine-to-Machine to the Internet of Things: Introduction to a New Age of Intelligence. Amsterdam: Elsevier. Academic Press. pp. 327.

https.//teara.govt.nz/files/p-23079-enz.jpg

https://en.m.wikipedia.org//wiki/food_extrusion

https://pfrymakoruma.com/wwen/machinedetails/maxxd/?gclid=EAlalqobChM19r2wrLA4wlVibTtCh3ggwi4E ASAYASAAEglsr_d_BwE

Hawken, P., Lovins, A. B., \& Lovins, L. H. (2013). Natural capitalism: The next industrial revolution. Journal of Finance, 48(3), 831-880. https://doi.org/10.4324/9781315065755

Inikori, J. E. (2006). Africans and the Industrial Revolution in England: A Studying International Trade and Economic Development. Cambridge, Cambridge University Press.

IFMT. (2020). International Food \& Meat Topics, 31(3), 16-19. Retrieved from http://www.positiveaction.info/magdetails.php?m=7

Klein, M. (2008). The Technological Revolution. Newsletter of Foreign Policy Research Institute, 13, 18.

Jee, Y. S. (2017). Exercise rehabilitation in the fourth industrial revolution. Journal of Exercise Rehabilitation, 13(3), 255-256. https://doi.org/10.12965/jer.1735012.506

Joel, M. (2003). The Second Industrial Revolution, 1870-1914. Rome: Laterza publishing.

Marwala, T. (2019). Fourth industrial revolution and Society. A public lecture delivered by the Vice-Chancellor and Principal of the University of Johannesburg in September 2019 at the University of Venda, South Africa.

Marwala, T., \& Hurtiz, E. (2017). Artificial intelligence and economic theory: Skynet in the market. Springer. https://doi.org/10.1007/978-3-319-66104-9

Marwala, T. (2020). Artificial intelligence is already responding to our needs. Retrieved from https://mg.co.za/opinion/2020-06-17-artificial-intelligence-is-already-responding-to-our-needs/

Malek, M. (2005). History of the 1st IR. New York MG: McGraw-Hill Companies.

Muntone, S. (2013). Second Industrial Revolution. New York: MacGraw-Hill Companies.

Maury, K. (2008). The Technological Revolution. NF Research Institute, 13, No. 18.

Min, X., Jeanne, M. D., \& Suk, H. K. (2018). The Fourth Industrial Revolution: Opportunities and Challenges. International Journal of Financial Research, 9(2). https://doi.org/10.5430/ijfr.v9n2p90

Nagendra, H., Bai, X., Brondizio, E., \& Lwasa, S. (2018). The urban south and the predicament of global sustainability. Nature Sustainability, 1, 341-349. https://doi.org/10.1038/s41893-018-0101-5

Nayyar, S., de Cleene, S., \& Dreier, L. (2018). Innovation with a Purpose: The role of technology innovation. 
World Econ. Forum, No. January, pp. 1-42.

Noonan, L. (2019). The Busines Times. Sunday Times. pp. 20. Retrieved from www.sundaytimes.co.za

Patrick, W., \& Clay, G. (2012). Francis Grist Mill" National Register of Historic Places-Nomination and Inventory. North Carolina State Historic Preservation Office.

Prisecaru, P. (2019). Challenges of the Fourth Industrial Revolution. Knowledge Horizons. Economics. Journal of Engineering, 8(1), 57-62.

Rifkin, J. (2011). The Third Industrial Revolution: How Lateral Power Is Transforming Energy, the Economy, and the World. Palgrave Macmillan: New York, NY, USA.

Rifkin, J. (2013). The Third Industrial Revolution: How the Internet, Green Electricity, and 3-D Printing are Ushering in a Sustainable Era of Distributed Capitalism. The World Financial Review.

Salmon, M. (1843). The Mechanics Magazine. Museum Register, Journal, and Gazette: Volume 38. Public domain edition. pp. 155.

Schwab, K. (2015). The Fourth Industrial Revolution: What It Means and How to Respond. Retrieved from https://www.foreignaffairs.com/articles/2015-12-12/fourthindustrial-revolution

Strozzi, F., Colicchia, C., Creazza, A., \& Noè, C. (2017). Literature review on the 'Smart Factory' concept using bibliometric tools. International Journal of Production, 4, 512-514. https://doi.org/10.1080/00207543.2017.1326643

Vernon, M. (2019). George Washington's Gristmill. Retrieved from https://www.nps.gov/nr/feture/places/13000227.htm

\section{Copyrights}

Copyright for this article is retained by the author(s), with first publication rights granted to the journal.

This is an open-access article distributed under the terms and conditions of the Creative Commons Attribution license (http://creativecommons.org/licenses/by/4.0/). 